\title{
The Political Economy of Brazilian Cultural Policy: A case-study of the Rouanet Law
}

Erwin Dekker ${ }^{1}$

Ana Carolina Rodrigues ${ }^{2}$

${ }^{1}$ Erasmus University Rotterdam, Erasmus School of History, Culture \& Communication

${ }^{2}$ Erasmus University Rotterdam, Erasmus School of History, Culture \& Communication

\section{Abstract:}

We provide an analysis of the effectiveness of the cultural policy in Brazil under the Rouanet law for the period 1993-2016. We find that the law, which provides tax incentives for donations to and sponsorships of the cultural sector, has exacerbated existing socio-economic inequalities, regional inequalities, as well as inequalities between artistic genres. The gifts have predominantly gone to already successful projects, sometimes even already profitable projects. On the flipside the gifts have primarily come from large, mostly partially state-owned enterprises, and acted as the equivalent of a tax-cut for these organizations. From the evidence it is not clear that any particular market failure is alleviated through the Rouanet Law, instead it seems that the system of indirect support leads to a strong control over the cultural sector by big business in Brazil. We use these findings to criticize much of the literature on cultural policy which tends to take Western well-developed institutions for granted. We argue that this literature is ill-suited to capture the economy of Brazil and other 'limited-access states', because of its implicit assumption of a pre-existing 'open-access state'.

\section{Key words:}

Cultural Policy, limited access orders, direct and indirect support, state capacity, economics of the arts

JEL codes:

Z18, O25, P16

\section{Word count:}




\title{
The Political Economy of Brazilian Cultural Policy: A case-study of the Rouanet Law
}

\author{
Abstract \\ We provide an analysis of the effectiveness of the cultural policy in Brazil under the Rouanet \\ law for the period 1993-2016. We find that the law, which provides tax incentives for \\ donations to and sponsorships of the cultural sector, has exacerbated existing socio-economic \\ inequalities, regional inequalities, as well as inequalities between artistic genres. The gifts have \\ predominantly gone to already successful projects, sometimes even already profitable \\ projects. On the flipside the gifts have primarily come from large, mostly partially state-owned \\ enterprises, and acted as the equivalent of a tax-cut for these organizations. From the \\ evidence it is not clear that any particular market failure is alleviated through the Rouanet \\ Law, instead it seems that the system of indirect support leads to a strong control over the \\ cultural sector by big business in Brazil. We use these findings to criticize much of the \\ literature on cultural policy which tends to take Western well-developed institutions for \\ granted. We argue that this literature is ill-suited to capture the economy of Brazil and other \\ 'limited-access states', because of its implicit assumption of a pre-existing 'open-access state'.
}

\section{Introduction}

An extensive literature in the field of economics of arts investigates the categorical question of whether government should support the arts. Such studies, however, are mainly focused on the reality of developed countries (King and Blaug 1976; Grampp 1989; Peacock 1994; Frey 2003; Zimmer and Toepler 1999), which represent the minority of countries in the globe. Therefore, this study aims at exploring if the arguments presented by the literature on state patronage of arts can apply to emerging economies, herein defined as low and middle-income countries with fragile institutions (North 1990; Acemoglu, Johnson, and Robinson 2001; Rodrik, Subramanian, and Trebbi 2004). The difference in institutions between these countries can also be described following North, Wallis and Weingast, as limited-access states and openaccess-states. In the former there is a dominant ruling coalition consisting of the groups who possess a potential for organized violence, and they partition economic and political power among themselves. Others are excluded and this leads to partial legal arrangements favoring the dominant coalition (North, Wallis and Weingast 2009). An open-access state on the other hand is marked by competition between various groups in society which puts pressure on the state to provide public goods. Economic power and political power are relatively independent of one another in such a state. 
We will argue in this paper that a central belief in the economic literature on public support for the arts does not hold in these countries. This central belief is that in general indirect subsidies are preferable over direct subsidies, since they better reflect the preferences of the citizens (West 1986; Schuster 1987; 1999; Netzer 2006; Towse 2010). This central belief, we will demonstrate, is discredited in two important ways in our case-study of public support to the arts in Brazil. Firstly, we show that the state and the private sector are hardly separated in this emerging economy, making any clear boundary between the two hard to draw. Together big business and the state form a ruling coalition. And therefore most of the relevant differences between direct and indirect subsidies disappear. But more importantly given the fact that state capacity is limited private parties are actually able to use the indirect subsidy arrangement to their private advantage, thereby undoing most if not all of the redistributive effects of the policy, and increasing the economic and social power of private actors over the cultural sector. We demonstrate that the indirect subsidy policy ends up benefiting the supporters, rather than the supposed benefactors.

Our argument is not merely one about corruption, although that occurs too, but is one written along the lines of modern state capacity theory. Our case-study demonstrates that when state capacity is weak typical arguments about favoured methods of public support do no longer hold (Besley and Persson 2009). Secondly we demonstrate that in the Brazilian case it is impossible to disentangle state and private sector from one another, upsetting some of the basic assumptions underlying models of public policy for the arts. In particular we demonstrate that the biggest art supporters in Brazil - via indirect subsidies - are state-owned companies. We argue that in order to understand such investments we cannot rely on a model that keeps the state and private sector separate, instead we should analyse them as bargains within the ruling elite of the country.

Our Brazilian case-study is based on original primary data, and highlights some of the most important outcomes of the Rouanet ${ }^{1}$ Law in Brazil. We show using a variety of data sources the impacts of this law, and in particular the resulting distribution of funds. The Brazilian case elucidates important differences from developed and emerging economies that have so far been neglected by the literature of cultural economics. It thus contributes to a better understanding of the effects of cultural policies in such settings. As such it can help nuance idealized notions of the state and generate more understanding about the challenges for cultural policy makers in limited-access orders (Berkowitz, Pistor, and Richard 2003; North et al. 2012).

\footnotetext{
${ }^{1}$ Sérgio Paulo Rouanet was the national Secretary of Culture during the period when Law No. 8,313 was created. He is also a member of the Brazilian Academy of Letters since 1992.
} 
The paper will proceed as follows. The first section develops in some more detail the standard theory of the effectiveness of public support for the arts, and the alternative perspective provided by entangled political economy. Section two presents the case-study of the Rouanet Law and its results. Section three interprets those results using the theory of open access-states and state capacity theory. Section four concludes with some implications for thinking about cultural policy in emerging and developing countries.

\section{Cultural Policy: Direct and Indirect}

In the existing literature on state support for the arts there are two primary concerns equity and efficiency. To promote efficiency the state is meant to correct certain market failures, which typically are said to lead to an underprovision or lack of demand for the arts. Prominently in the literature have been concerns about the positive externalities of arts production and consumption, and concerns with taste development. Another set of arguments in favour of public support have highlighted equity concerns, such as access for low-income groups to the arts, as well as regional policies which seek to promote the arts and creative sector in particular areas (nowadays often as an economic development strategy) (Frey 2003; Ploeg 2006; Throsby 2010).

Although most cultural economists agree that there is a viable case for state intervention in the arts, it is well recognized that the state faces an information problem when it comes to supporting the cultural sector. The major worry is to ensure the right type of projects or organizations receive support. One prominent suggestion to overcome this problem is to argue against overreliance on supply-side subsidies to producers of arts, and instead to favour voucher-schemes. There is relatively widespread agreement that this would lead to a more demand-responsive arts sector, although adoption of this type of support has been far less widespread.

Similar reasoning has been used to suggest that it would be preferable to provide tax incentives for charitable giving to cultural organizations (indirect support), rather than to provide the support from tax revenues (direct support). This would have the dual benefit that it would reveal the preferences for support to particular cultural organizations, and it would make the cultural organizations more responsive to the wishes of various groups in society including donors and the public. Although some have expressed worries that this might limit the autonomy of the relevant organizations (Frey 2003). Finally it has been suggested that indirect support from civil society actors create more active engagement with cultural organizations. 
The arguments for indirect support over direct support, has perhaps not been quite as widespread as that for demand-side subsidies, but there is still a strong case made by economists of the arts in favour of indirect support (Schuster 1999). Again, practice has not reflected this belief, and except in Anglo-Saxon countries most government policy for the arts still takes place through direct support. Notwithstanding this fact, there have been a variety of attempts to place cultural-policy at arm's length of the government to prevent all too easy government-capture. The resulting specialized committees should prevent too much direct influence of the state over the cultural sector, and at least nuance the extent to which there really is 'direct support'. Both direct and indirect support tend to go to non-profit organizations, which might undercut the overall responsiveness of these organizations to consumer demand.

Public choice approaches have made relatively few inroads in the cultural sector. Although some attempts were made during the 1990's they appear to never have become prominent (for an overview see Mazza 2003). This despite the obvious danger that big cultural organizations collude with the government, and the fact that big cultural events such as festivals might provide politicians with temptations similar to those of big infrastructure projects: they make 'achievements' highly visible. If there is any political-economic approach it has tended to be critical of a recent 'neo-liberal' turn in cultural policies, but those issues do not concern us here (Belfiore 2004).

We instead suggest that a modern state capacity theory does far more justice to the institutional complexities of cultural policy. State capacity theory argues that effective policymaking requires sufficient state capacity, which would lead to an open-access order. A lack of state-capacity can result from international factors, but is more often theorized as resulting from domestic conflicts between elites. A situation of low state capacity and the accompanying limited-access order is a political equilibrium "in which elites restrain from violence as long as expected rents in the current political arrangement are greater than the expected value of fighting" (Fargias 2018: 341). This theory is explicitly developed in relation to economic development, a feature lacking from traditional public choice approaches.

This leads to a recognition of the variety of institutional settings under which cultural policy is made, and how such institutional settings influence the expected outcomes. We will demonstrate in our case-study that in emerging economies where state and private sector are far from separated but instead often form a dominant coalition traditional expectations (based on Western experiences with cultural policies) do not hold. Cultural policy in Brazil is not widely studied, let alone critically analysed. The recent report on Brazil's creative economy from the British Arts Council pays little attention to governance structure, although two issues 
we explore below are at least flagged: the entanglement between business and state, as well as the great disparities in the economy (Fleming 2018). But the report is also typical as thinking of political issues as being outside of the realm of cultural policy, or acting upon it as a kind of external constraint (see also Marsh 2016).

\section{Case study: state patronage of arts in Brazil}

This section turns to a closer look at the state patronage of arts in Brazil. Our case-study is limited to one country, but we hope to illuminate broader political economic issues regarding cultural policy at stake in other emerging economies as well as to a lesser extent those in advanced economies. For our data we have relied on secondary sources where available and some primary sources where relevant. Such analysis will be made based mainly on official data from the Brazilian Ministry of Culture (MinC), Brazilian Population Census (IBGE), the World Bank and Unesco Institute for Statistics on public education and levels of income, as well as on the corruption perceptions index (CPI).

\subsection{Brazilian policies for arts support: the Rouanet Law}

This study will be based on the analysis of the Rouanet Law, which establishes a tax-based incentive to the supply side of the Brazilian arts market. Although there are other laws (in the federal, state and municipal level) to develop the cultural sector in Brazil, the Rouanet Law is the most important one in terms of volume of resources invested in the cultural sector (Arminda do Nascimento Arruda 2003).

According to the official data provided by the Ministry of Culture at the website of Salic (Sistema de Apoio às Leis de Incentivo à Cultura), from 1993 to 2016 more than $\mathrm{R} \$ 18$ billion (approximately USD 5.75 billion) have been invested in culture by means of Rouanet Law. During the period, almost 200,000 projects have been proposed, out of which $55 \%$ have been approved by the governmental bodies and $25 \%$ have been actually supported by sponsors and donors via Rouanet Law. Graph 1 below illustrates the evolution of projects proposed, approved and supported from 1993 to 2016.

\section{Insert Graph 1 here.}

The most important mechanism created by the Rouanet Law was the "incentive to cultural projects", also called as tax incentive, which is a mechanism by means of which the federal government allows individuals and legal entities to use portions of the income tax (up to $6 \%$ or $4 \%$, respectively) as donations (i.e. anonymous contribution) or sponsorships (i.e. contribution 
with publicity for the supporter) to directly support cultural projects. The value of the donation or sponsorship can be partially or fully deducted from the due income tax (depending on the invested cultural sector, the nature of the support - donations or sponsorships - and/or the category of the supporter taxpayer - i.e. individuals or legal entities).

Section $18, \S 3$ o of the Rouanet Law lists the art categories that entitle the deduction of the full amount invested by the taxpayers in approved cultural projects, regardless of the nature of the support or the category of the supporter taxpayer. All other art forms not explicitly mentioned in the provision referred above entitle only a partial deduction from income tax. The amount of partial deduction varies as follows: up to (i) $80 \%$ for donations made by individuals, (ii) $60 \%$ for sponsorships carried out by individuals, (iii) $40 \%$ for donations made by legal entities and (iv) 30\% for sponsorships carried out by legal entities. Table 1 summarizes the thresholds of the tax incentives:

\section{Insert Table 1 here.}

The possibility of full deduction of the amount of taxes paid is internationally unusual and frequently criticized, typically such arrangements allow one to deduct the donated sum from one's taxable income or profits, not from the actual taxes due. It entails the possibility of not paying part of one's taxes, while enjoying the benefit of deciding on the allocation of public money (Belem and Donadone 2013).

In order for projects to be eligible under the Rouanet law they have to be approved. The application process is initiated by the artist, producer or cultural agent. The project is subsequently evaluated by several governmental bodies which will approve or reject the projects. In case of approval of the project, the applicants are responsible for finding eligible supporters.

In 2010 a bill has been proposed to repeal the Rouanet Law and to establish new rules for culture and arts funding. The approval of the referred bill - PL 6,722/2010 - is still pending and subject to amendments or rejection. The primary change under the new bill would be the abolishment of full tax deduction provided by section 18 (only partial deductions would apply) and the empowerment of the government, which would have a more significant role in the allocation of the funds. But since the bill is still pending approval, the analysis of the proposed new rules will not be part of this work.

\subsection{The (Cultural) Economy of Brazil}

According to the IMF database, Brazil has the $9^{\text {th }}$ highest GDP in the world, and is the biggest 
economy of Latin America. Nonetheless, in terms of GDP per capita Brazil was almost $20 \%$ below the global average in 2018. The country is plagued by high levels of corruption as has been very evident with high politicians being caught up in scandals, as well as high social and economic inequality. The $20 \%$ of the people with the highest income earned $56.3 \%$ of the total income. The economic inequality is also reflected geographically. According to IBGE, in 2016 the difference between the amount of average income per capita between the richest and poorest federal units was greater than $400 \%$. The North and Northeast areas of the country are the poorest ones, while the highest level of incomes are mostly concentrated in the South and Southwest areas, particularly in the big cities. This pattern is also present in terms of education. According to the database of Atlas do Desenvolvimento Humano no Brasil, produced by the United Nations Development Programme (UNDP) in cooperation with some Brazilian entities, illiteracy is concentrated in the North and Northeast areas of the country.

According to the World Bank, despite the poverty reduction over the last decade, there is still a high level of inequality in Brazil. The country managed to achieve universal coverage in primary education, but is struggling to improve the outcomes of the lower and upper secondary levels of education. The concentration of income and precariousness of education are reflected in the consumption of artistic-cultural goods and services in Brazil. There is clear evidence that the consumption of arts and culture in Brazil is "unequally distributed among the population, being determined mainly by education and income" (Diniz and Machado 2011, 17). This is also the conclusion of the report released by IBGE in 2013 on the information and indicators of culture. According to the research, the poorer the Brazilian family, the lower its expenditures with culture. Families with an income greater than $R \$ 6,225.00$ spend approximately 17 times more in culture than families with an income up to $R \$ 830.00$ (Instituto Brasileiro de Geografia e Estatística 2013, 216). Likewise, families whose head of the householder has university level education spends on average six times the amount spent by families whose householder has no education or incomplete elementary school level.

There is also widespread (perceived corruption). In 2017 Brazil scored 37 points on to the corruption perceptions index, on a scale of 0 to 100 where 0 represents the highest level of corruption. This is in line with other South-American countries, and places Brazil at place 96 in the world out of 180. According to a survey called "Interesse Público e Corrupção" conducted in the years of 2008 and 2009 by a centre of research of the federal university of the state of Minas Gerais in cooperation with Instituto Vox Populi, a Brazilian company specialized in survey researches, $73 \%$ of the Brazilian citizens considered corruption as a very serious issue in the country, whereas $24 \%$ consider it serious. Given the recent scandals at the highest levels of Brazilian politics it is likely that these figures have only risen since. 
This is unlikely to change in the short-run. The literature argues that corruption in Brazil can be explained by its historical origins, particularly by the Portuguese colonialism (Faoro 2013; Mello 2008). According to Faoro (2013), during the colonization Brazil has inherited the Portuguese patrimonialism, which was characterized by three main aspects: the lack of separation between the public and private spheres, the detachment of public agents from society, and state-directed capitalism. According to Baquero (2015, 147): "the history of Brazilian political culture marked by patrimonialism and individualism obstructed the differentiation between public and private spheres, facilitating corruption practices within and without public institutions". This is not to say that we believe current policy outcomes are mostly historically determined, rather that such patterns have existed for a long period of time as suggested by the theory of state capacity, which suggests breaking the equilibrium of weakstate capacity is difficult.

\subsection{Empirical analysis of Rouanet Law}

The evaluation of policy is typically a contested effort, what should count as success. In this case-study we have opted to stick to some objective measures, rather than an evaluation of the stated goals of the policy. We believe that the results will demonstrate that it is hard to contest the failure of the policy, under most feasible sets of goals. The empirical analysis of Rouanet Law is structured in six parts, each of them analyzing the following: (i) which are the main sources of Rouanet Law funds, (ii) what motivates supporters to invest in cultural projects, (iii) where the subsidies go in terms of geographical distribution, (iv) artistic genres which benefit the most from Rouanet Law, (v) corruption issues in connection with the subsidies granted via Rouanet Law, and (vi) the main changes to the Rouanet Law introduced by a normative instruction created by the Ministry of Culture.

\subsubsection{Where does the money come from?}

The investments in cultural projects via Rouanet Law can be supported by (i) individuals or (ii) by companies that pay income taxes based on their actual net income (i.e. Lucro Real) ${ }^{2}$. In Brazil, there are different tax regimes to calculate the due income tax of legal entities and they vary mainly based on the value of gross revenue. The calculation of income tax based on the Lucro Real method is mandatory for companies whose total gross revenues exceed $R \$ 78$ million per year (around USD 25 million). Consequently, most companies whose total gross revenues is lower than $\mathrm{R} \$ 78$ million are not entitled to the tax deductions provided by

\footnotetext{
${ }^{2}$ There is a proposal in place to extend benefits of Rouanet Law to companies taxed under other regimes.
} 
Rouanet Law. As a result, Rouanet Law creates an advantage that primarily applies to large companies. According to Augustin $(2016,13)$, in 2009 only thirty companies were responsible for half of the total amount invested via Rouanet Law. Such companies were mainly from the most concentrated sectors, such as the finance, steel and energy, which also happen to be the industries with heavy state involvement.

Another study estimated the average revenues of the supporting companies in 2005 . To do so, the total amount of investments via Rouanet Law in 2005 (i.e. $R \$ 677$ million) was divided by the total number of supporting companies (i.e. 1,956). The result (i.e. $\mathrm{R} \$ 346,000.00$ ) indicated the average amount invested per supporter. The scholar considered that companies can deduct up to $4 \%$ of the due tax income, so that he was able to estimate the average amount of due income tax per company (i.e. $\mathrm{R} \$ 8.65$ million). Considering that the due income tax corresponded to $15 \%$ of the total profit, the total net profit would correspond to $\mathrm{R} \$ 57$ million. The author considered a mark-up of $20 \%$ over the revenues, which indicated a total revenue of $\mathrm{R} \$ 288$ million (Cavalcanti 2006).

It is worth noting that such a calculation is simplified and presents some limitations. First, it ignores the fact that the total amount of investments via Rouanet Law comprises not only the support from legal entities, but also the amounts invested by individuals. But since individual donations make up less than $1 \%$ of the amount invested they might be ignored. Second, the amount of tax deduction may vary, it is not necessarily a full deduction. But adjusting for this would only mean we would arrive at higher estimates. Third, there is no explanation to justify why the mark-up over revenue was set as $20 \%$. Despite the limitations mentioned above, the literature has presented no alternative methodology to estimate the revenues of supporter companies in a more accurate way.

Therefore, if we replicate the methodology in this study for the last five years (i.e. 2012 to 2016), with the adjustment to consider only the support provided by legal entities, the results indicate an average revenue above $\mathrm{R} \$ 300$ million, as detailed in the table 2 .

\section{Insert table 2 here.}

It is worth highlighting that according to Brazilian Law $11,638 / 07$, companies with a gross revenue higher than $\mathrm{R} \$ 300$ million are classified as large-sized companies. In this sense, it would be possible to conclude that most of the funds raised by Rouanet Law come from largesized companies. Additionally, the Rouanet Law primarily benefits highly profitable 
corporations. Since tax incentives are only applicable to profitable companies (if there is no profit, there is no due tax income), and considering that the incentive is calculated as a percentage of the income tax, the higher the profits, the higher the tax incentive. Therefore, the tax incentive generated by Rouanet Law, subsidizes not only cultural projects, but also the cultural marketing of major for-profit corporations, as explained in more detail in section 2.3.2.

Another important finding regarding the major supporters under the Rouanet regime is the strong presence of state-controlled companies and quasi-governmental companies as the main supporters of the projects. According to a report prepared by SEBRAE (Serviço Brasileiro de Apoio às Micro e Pequenas Empresas), an institution supporting the development of small and micro companies in Brazil, 2,462 projects (more than $80 \%$ of the projects in table 3 ) were supported by companies having at least a minority shareholding held directly or indirectly by a governmental or governmental-related entity (companies ranked as 1-5 and 8-9) and 2,213 projects (more than $73 \%$ of the projects listed in table 3 ) were supported by state-controlled companies (companies ranked as 1-4 and 8-9). This situation reflects the entangled relationship between politics and markets, which act as "overlapping subsystems of human interaction within a society" (Tuszynski and Wagner 2015, 106). For instance, an analysis of the Bovespa Index (Ibovespa), composed by the more actively traded and better representative stocks of the Brazilian stock market, shows that most of the participation in the Ibovespa (i.e. $52.6 \%)$ is held by companies that have at least a minority shareholding held directly or indirectly by a governmental or governmental-related entity.

\section{Insert Table 3 here}

\subsubsection{What are the motivations to support cultural projects?}

It might be argued that despite the strong concentration of donations/sponsorships among (partly) state-owned large corporations, the investments could still be given by those with an interest and motivation to support the arts. A research conducted by Fundação João Pinheiro, under the request of the Ministry of Culture, has revealed, however, that this is also not the case (Fundação João Pinheiro 1998). Based on a survey applied to a sample of 111 companies their main motivations to support cultural projects they conclude that companies are mainly motivated by publicity strategies, rather than social purposes. The main motivation for companies to invest in cultural projects was the promotion of institutional image. Such motivation has been mentioned by more than $65 \%$ of the companies, while less than $24 \%$ 
mentioned the reinforcement of the company's social rule as a reason for the support (multiple answers were possible). Table 4 presents more details on the matter.

\section{Insert Table 4 here}

In this sense, Barbalho (2007) explains that a common critique from the artists and cultural producers to the Rouanet Law is that companies are only interested in projects that have media visibility and audience appeal. Therefore, projects in areas that traditionally get less exposure to the media and large audiences struggle to raise funds through the Rouanet Law. As we will see below, this results in investments ending up highly concentrated among already popular artists and institutions. This view is corroborated by Ponte $(2012,35)$ who argues that the fact that the decisions on public investment in arts and culture are taken by the marketing departments of large companies can directly interfere in the artistic purpose or in the format of the cultural project.

According to Mega $(2015,57)$, the sponsorship guidelines of some supporters including private and state-owned companies - such as Santander, Eletrobras, Natura, Correios and Volkswagen explicitly impose restrictions to the freedom of artistic expression and creativity by means of prohibiting cultural projects that are connected with polemic issues such as violence, drugs, weapons and pornography. Such preferences of supporters are of course legitimate and are to be expected in any indirect support system, but if investments are so concentrated it might still be considered problematic.

\subsubsection{Where does the money go?}

In this section we are again relying on the official information collected by Salic, for the amount of tax expenditures invested in culture by means of the Rouanet Law during the five year period from 2012 - 2016. The analyzed data indicates a substantial geographical disparity on the amount of funds invested by means of the Rouanet Law. As graph 2 shows there is a huge concentration of investments in the Southeast area of the country, while the Northeast and North receive much more modest sums.

\section{Insert Graph 2 here.}

The data also indicates that there is an enormous concentration of resources in the richest federal units. The five richest federal units (out of 27) in terms of average income per capita (i.e. Distrito Federal, São Paulo, Rio Grande do Sul, Santa Catarina and Rio de Janeiro) account 
for approximately $84 \%$ of all Rouanet Law funds invested in 2016 . On the other hand, the five poorest federal units (i.e. Maranhão, Alagoas, Pará, Amazonas and Piauí) account for less than $1.5 \%$ of such funds.

Such disparities cannot be explained by means of concentration of population. The disparity in the allocation of subsidies is much higher than the discrepancies in population density (projected by IBGE). For instance, the state of São Paulo, the most populous one, is home to around $21 \%$ of the total population of the country and received in 2016 almost 50\% of all the resources obtained via Rouanet Law. Likewise, the state of Rio de Janeiro is home to around $8 \%$ of the population and received in 2016 more than $20 \%$ of the subsidies from Rouanet Law. Graph 3 illustrates the levels of population and concentration of Rouanet Law funds in each of the five Brazilian federal units most benefited by Rouanet Law in 2016 .

\section{Insert graph 3 here.}

The geographical inequality is also evident when comparing the per capita distribution of funds from the Rouanet Law in each federal unit. Alagoas, in the North region of the country, is the federal unit that received the lowest amounts of Rouanet Law subsidies per capita in 2016, a total of only $\mathrm{R} \$ 0.01$ per inhabitant. On the other hand, the highest amount of subsidies per capita was received by Distrito Federal, the capital of the country, and corresponds to R\$ 21.07. That amount is nearly four times the national average and 2,107 times the per capita amount received by Alagoas.

When comparing the regions, the Southeast received in $2016 \mathrm{R} \$ 9.80$ of subsidies per inhabitant, while the Northeast area received only R\$ 0.57 of subsidies per inhabitant, corresponding to around $181.8 \%$ and $10.6 \%$ of the national average, respectively. Table 5 presents the amounts of subsidies per capita for each federal unit and per region.

Insert table 5 here. 


\subsubsection{Which art forms benefit from the Rouanet Law?}

In addition to the regional concentration of subsidies, the funds from the Rouanet Law are also heavily concentrated in terms of artistic genres. The supported projects are classified into seven categories. Graph 4 demonstrates from 2012 to 2016 the subsidies have been mostly concentrated in performing arts (33\%), followed by music (23) and visual arts (16\%).

\section{Insert graph 4 here.}

The concentration of funds in certain genres may be partially explained by the fact that they go to the most costly genres in terms of production costs. Nonetheless, there are three other reasons that may also help to explain such allocation of funds: (i) cultural marketing strategies, (ii) levels of tax deduction, and (iii) complexity of the application process.

First, supporters decide which project to support based on their marketing strategies. As explained by Mega (Mega 2015, 4), supporter companies tend to invest in large shows that proportionate high levels of media exposure and attendance. Such kind of events are more likely to happen in the performing arts (e.g. adaptations of Broadway plays), music (e.g. music festivals with superstars) and visual arts sectors (e.g. exhibitions of prestigious artists). Often these projects are already profitable without the donation. In 2011 approximately R\$45 million of the funds raised by Rouanet Law have been invested in large Broadway productions. This amount corresponds to more than $15 \%$ of the Rouanet Law subsidies directed to performing arts in 2011. According to the author, these blockbuster events garner high levels of publicity to the supporter companies, and consequently contribute to add value to their brands.

Second, supporters tend to prefer to invest in sectors that entitle full deduction of the investment (sectors listed in section 18 of Rouanet Law). This could explain why investments in performing arts are higher than in music, since all investments in performing arts allow full deduction, while only investments in instrumental and classical music are fully deductible.

Third, the concentration of investments in certain genres may also indicate that the bureaucracy for proposing projects is likely to deter the less privileged artists and producers from less appealing segments such as integrated arts - from seeking for subsidies, since they do not have trained people to help them with the application process. The high levels of bureaucracy and the complexity of the application process have been acknowledged by the Ministry of Culture, which has formally proposed adjustments to the Rouanet Law to reduce the bureaucracy and to prohibit the use of intermediaries in the application process (as per section 37 of the PL 6,722). As explained by Barbalho (2007), artists are increasingly required to get professionalized by means of hiring a team of support professionals, such as producers, 
fundraisers, researches and marketing professionals, which consequently tends to exclude the artists who are not already established.

\subsubsection{Corruption in connection with Rouanet Law}

According to the regional chief of the Office of the Comptroller General in the state of São Paulo $87 \%$ of the projects financed by the Rouanet Law contain serious failures to comply with the rules in the law. This conclusion comes from the analysis of a sample of 34,000 cultural projects from 1992 to 2015. The Communication Department of the Attorney General's Office in the State of São Paulo, on June 28, 2016 has announced an operation aimed to investigate the (potential) abuse of federal funds, called Operation Freeload. They estimated that fraudulent behavior was present in many cases and caused a loss of approximately $R \$ 180$ million to public purse (around USD 57 million). The Federal Police believe that the irregularities may include, among other aspects, the return of part of the donated funds to supporter companies. According to the Ministry of Culture, there are approximately 18,000 projects whose accountability assessment is still pending.

Moreover, the Brazilian Federal Court of Accounts (TCU) has investigated alleged irregularities in the financial support approved by the Ministry of Culture based on Rouanet Law to some cultural projects, such as Rock in Rio, a major musical festival. As a result of the investigations, TCU recommended the Ministry of Culture not to authorize the raising of funds to projects that present a strong potential to be profitable or have the capacity to attract sufficient private investments. According to the TCU's decision, the practice of charging prices that cannot be considered accessible to society in general conflicts with the purposes of the Brazilian Federal Constitution and the Rouanet Law, which aims at assuring access for all citizens to cultural events and access to the sources of national culture (as per section 215 of the Brazilian Federal Constitution and section $1^{\text {st }}$ of Rouanet Law).

Finally, it is worth mentioning that corruption is also present within some important supporters. For instance, Petrobras, the Brazilian state-oil company which supported the largest number of projects within the period from 2008 to 2013, wrote-off an amount of $R \$ 6.2$ billion (at the time approximately USD 2 billion) due to alleged bribery payments in 2014 . Likewise, BNDES, which was also among the largest supporters of cultural projects via Rouanet Law in the referred period, is being investigated by the Federal Police under the investigation called Operação Bullish, initiated in May, 2017. The investigation aims at clarifying alleged frauds and irregularities within the granting of funds by BNDES to JBS, a company controlled by J\&F, who entered into a leniency agreement with Federal Public Prosecutor's Office after 
confessing the involvement in a corruption scheme. It is worth mentioning that BNDES indirectly owns more than $21 \%$ of JBS's shares, which also emphasizes the entangled relationship between the public and private sphere.

\subsubsection{Suggested Reforms}

In response to the regional disparities and high prices of cultural products and services funded by means of the Rouanet Law, the Ministry of Culture released on December 26, 2017 the Normative Instruction 5/2017 (IN 5/2017) aiming at assuring the fundaments of the law: fomenting national culture in a decentralized way, democratizing the access to the resources from the tax incentives and to the cultural goods supported by Rouanet Law. The new rules try to induce the increase of projects mainly in the North, Northeast and Midwest regions, but also in the South and part of Southeast regions by means of increasing the thresholds of number of projects per proponent and resources per proponent for projects carried out in such areas ("Thresholds").

Therefore, the IN 5/2017 states that the referred thresholds can be increased up to (i) $50 \%$ in the North, Northeast and Midwest regions and (ii) $25 \%$ in the South region and in two states of the Southeast region (i.e. Minas Gerais and Espírito Santo). The first possible problem of such measures is that the Midwest area includes Distrito Federal, which is the richest federal unit of the country in terms of average income per capita, and the federal unit that received the highest amounts of Rouanet Law subsidies per inhabitant in 2016. In addition, analyzing the numbers of the last five years (i.e. 2012 - 2016), Distrito Federal has been always one of the five federal units most benefited by the Rouanet Law in absolute values, as detailed in the table 5 .

\section{Insert Table 5 here.}

In this sense, supporters may opt to invest in Distrito Federal to benefit from the higher thresholds, rather than investing in less privileged areas. If that happens, the decentralization pursued by the law will be unlike to happen. The same holds for Minas Gerais, which has also been among the five states which most benefited by the Rouanet Law in the past 5 years.

Another weakness of the IN 5/2017 relates to the thresholds themselves. Article 4 of the IN 5/2017 states that the proponents (legal entities) shall not have more than sixteen projects supported by the Rouanet Law and that they shall not receive more than $\mathrm{R} \$ 60$ million (except in some specific cases, such as annual or biennial plans, where the monetary thresholds do not 
apply). To make matters worse there is a condition that within a long-term plan the total sum can still be used in one single project. Our data indicates that such thresholds do not seem actually restrictive to the proponents. For instance, seven out of the ten largest proponents invested the funds in annual and biennial plans, which are not subject to the limitations. Additionally, none of the ten largest proponents in 2016 reached the limits of $\mathrm{R} \$ 60$ million or the sixteen projects threshold. Table 6 provides more details.

\section{Insert Table 6 here.}

It is therefore unlikely that the changes introduced by IN 5/2017 are sufficient to promote the decentralization of investments made under the Rouanet Law. This is especially true in light of the fact that the Rouanet Law has become an important instrument of cultural marketing for the sponsoring companies (Calabre 2007).

Another concern addressed by the IN 5/2017 relates to the price of the cultural services and goods subsidized by the Rouanet law. The rules establish that (i) at least $10 \%$ of the tickets shall be distributed free of charge to the population, (ii) up to $10 \%$ can be distributed free of charge to the sponsors, (iii) up to $10 \%$ can be distributed free of charge to advertising purposes, (iv) at least $20 \%$ shall be commercialized for no more than $\mathrm{R} \$ \mathbf{7 5}$ (corresponding to $7.5 \%$ of the current monthly minimum wage or approximately $7 \%$ of the Brazilian average income per capita in 2016) and (v) up to $50 \%$ can be commercialized for an average price equal or lower than $\mathrm{R} \$ 225$ (corresponding to $24 \%$ of the current monthly minimum wage or of approximately $21 \%$ of the Brazilian average income per capita in 2016).

The careful analysis of such numbers also seems to stress the weakness of IN 5/2017 to promote democratization of access. According to the data from Eurostat (2010), private consumption expenditure on culture-related goods and services in Europe as a share of total household expenditure averages 3.6\%, with just few countries exceeding 5\% (i.e. Denmark, Sweden and United Kingdom). In Brazil, according to Diniz \& Machado (2011), the expenditures on cultural-artistic goods and services account for less than $1.5 \%$ of the total household expenditure. In this sense, the maximum prices established by the IN 5/2017 for the cultural tickets and goods are still very high and unlikely to actually democratize the access to culture.

\subsection{State patronage of arts and the crowding-out effect}

Crowding-out is typically considered to be the effect of increased state support on the level of private support. But in our case we must think of it as the influence of the Rouanet Law on 
private support outside of the framework of the Rouanet Law. These effects have been studied by Earp and Estrella (Earp and Estrella 2016). Their results demonstrate that in 1996 the real value of the amounts raised for arts and culture by means of tax deductions totalled around $\mathrm{R} \$ 133$ million, in 2014 this amount increased to approximately $\mathrm{R} \$ 1,260$ million. The private investments, on the other hand, amounted R\$230 million in 1996 and decreased to R\$74 million in 2014. The crowding-out effect is illustrated by in graph 5.

\section{Insert graph 5 here.}

Graph 6 compares the real value of the investments made by means of private capital and tax deductions from 1996 to 2014:

\section{Insert Graph 6 here.}

The main reason for the dramatic decrease of private support is the amendment of Rouanet Law in the second semester of 1997 by means of the Medida Provisória 1,589/97 (Belem and Donadone 2013,56$)$. The new rule introduced the possibility of deducting $100 \%$ of the sponsorship or donation for cultural projects in certain sectors (i.e. the ones listed by section 18 of Rouanet Law).

\section{Analysis}

The data strongly suggests that the Rouanet Law fails to achieve any of the stated or reasonably accepted aims of a policy aimed to support the arts. The policy does not stimulate more experimental forms of arts, does not increase access to the arts for lower income groups, does not lead to regional redistribution of funds, and it is not clear from the evidence that any particular market failure is alleviated through the support. Instead it seems that the system of indirect support leads to a strong control over the cultural sector by some of the major companies in Brazil. These big companies are frequently state-owned or quasi-governmental companies. As such it is a question whether we really should be speaking of a system of indirect support, since it appears that different parts of the government than the ministry of culture is in control of the funds that go to the cultural sector. 
The money ends up with a relatively small number, often already profitable, organizations in the form of sponsorships rather than donations. Geographically the money is highly concentrated in the most developed areas and in particular cities within the country. Similar to other parts of the economy, here too there are significant signs of serious corruption, including the funnelling back of sponsorship money to the 'donating' companies. Attempts at reform have been unsuccessful or inconsequential. And private support outside of the framework of the Rouanet law has nearly dried up, while the overall level of support has not increased much.

So while a system of indirect support has been implemented, this has not lead to the supposed benefits of such a system. Rather it has given the business sector nearly complete control over cultural policy in Brazil. This business sector, at least the biggest businesses (and supporters of the arts) are mostly state-owned enterprises. So it is even unclear whether we should really speak of indirect support here.

This problem of the entanglement of the public and private sector is left unaddressed in current discussions about support to the arts. From the standard cultural policy perspective it might be argued that Brazil is suffering from high levels of corruption which prevent effective cultural policy. But we think that the data actually shows that this is not merely corruption, although that occurs as well, but rather the effects of bargains with the ruling coalition. From the perspective of state capacity theory, we should consequently analyse the situation as one which is the outcome of such bargains and which seek to secure the economic and political base of this coalition. The case-study also shows that the cultural sector is believed to be important enough to be controlled by this ruling coalition, so as to neutralize its potentially disruptive effects.

It is clear that the state-owned and quasi-governmental enterprises have been treated very favourably by the Rouanet Law, which allows them to invest parts of their due taxes to the cultural sector. This means in fact that in the current situation that the state-owned and quasi-governmental enterprises are currently in control of arts policies in Brazil, and it is unlikely that they are willing to give this up without extensive compensation.

Future attempts to improve arts policies in Brazil should therefore not merely seek to overcome particular forms of corruption, but the ministry of culture should first aim to retake control over cultural policy. This is unlikely to be an easy trajectory (North et al. 2012). What has in fact happened is that powerful corporations are using their economic power to obtain other types of power in Brazilian society. For the period we have analysed this is particularly 
strong, but it should be noted that any type of indirect support system has this inherent danger. In the United States for example the Rockefeller and in particular the Ford Foundation have for a long-time been the major benefactors to the arts (Kreidler 1996). It seems therefore that there are good reasons to re-evaluate the general preference for systems of indirect support in the arts.

This might be more generally true in emerging economies in which there often is no extensive policy tradition in fields such as the arts, which in most Western countries is only a post-WWII phenomenon. When such a policy tradition is absent it might be more important to first establish one through direct support with a clear agenda. That is, of course, if one believes that the arts sector is one in which government intervention is legitimate in the first place.

\section{Conclusion}

Our case-study of the Rouanet Law in Brazil has highlighted its particular effects through the examination of the origins of funds, the benefactors and the extent to which funds are used appropriately. We have demonstrated that existing inequalities are reinforced by the Rouanet Law, that funds mostly come from state-owned or quasi-governmental enterprises which use the support for branding and marketing, and that corruption is a frequent occurrence. We have also demonstrated that neither social goals (more access) nor regional goals (spreading of arts) are achieved.

These results demonstrate, we believe, that many of the basic notions that underlie the standard framework of analysis of cultural policies with the economics of the arts break down in different institutional settings. In our case-study we demonstrated that there was no clear distinction between the public and the private sector, but rather both were governed by a dominant coalition. We have argued that changes in cultural policy itself will unlikely be effective if Brazil retains characteristics of a limited access order. In such a situation many of the standard prescriptions such as a preference for systems of indirect support rather than direct state support do not hold, or should at least be seriously bracketed.

We believe it is of great importance that economists concerned with cultural policy take a greater interest in the institutional foundations, and the underlying state capacity on which cultural policy is build. This has the potential to markedly improve the understanding and analysis of current cultural policies, and might help to improve them in the future. In particular this is of relevance since cultural policies, including the development of the creative industries, is now often actively promoted as a strategy of economic development. If economic 
development is the goal, than the challenges of economic development should be far better understood in the literature on cultural policy and cultural economics.

No special funding was received for this research project.

The Authors declare that there is no conflict of interest.

Acknowledgements: We would like to acknowledge the valuable feedback from Arjo Klamer and the participants of the Global-South Cultural and Creative Industries at the Erasmus University Rotterdam.

\section{References}

Acemoglu, Daron, Simon Johnson, and James A Robinson. 2001. "The Colonial Origins of Comparative Development: An Empirical Investigation." The American Economic Review 91 (5): 1369-1401.

Arminda do Nascimento Arruda, Maria. 2003. "A Política Cultural : Regulação Estatal e Mecenato Privado." Tempo Social 15 (2): 177-93.

Augustin, Andre C. 2016. "O Neoliberalismo e Seu Impacto Na Política Cultural Brasileira."

Baquero, Marcello. 2015. "Corruption, Political Culture and Negative Social Capital in Brazil." Revista Debates 9 (2): 139-57.

Barbalho, Alexandre. 2007. "Políticas Culturais No Brasil: Identidade e Diversidade Sem Diferença." In ENECULT - Encontro de E Studos Multidisciplinares Em Cultura. Salvador. http://hugoribeiro.com.br/biblioteca-digital/Barbalho-politicas_culturais_no_Brasil.pdf.

Belem, Marcela Purini, and Julio C Donadone. 2013. "A Lei Rouanet e a Construção Do 'Mercado de Patrocínios Culturais.'” Novos Rumos Sociológicos 1 (1): 51-61.

Belfiore, Eleonora. 2004. "Auditing Culture." International Journal of Cultural Policy 10 (2): 183-202.

Berkowitz, Daniel, Katharina Pistor, and Jean-Francois Richard. 2003. "Economic Development, Legality, and the Transplant Effect." European Economic Review 47: 165-95.

Besley, Timothy J, and Torsten Persson. 2009. "State Capacity, Conflict and Development." 15088. NBER Working Paper Series. Cambridge, MA.

Calabre, Lia. 2007. "Políticas Culturais No Brasil: Balanço e Perspectivas." In NECULT - Encontro de E Studos Multidisciplinares Em Cultura. Salvador.

http://rubi.casaruibarbosa.gov.br/bitstream/fcrb/451/2/Calabre, L. - Politicas Culturais no Brasil.

Cavalcanti, G E L. 2006. "Análise Econômica Das Políticas de Incentivo à Cultura No Brasil." Escola de Pós Graduação em Economia da Fundação Getulio Vargas.

Diniz, Sibelle C, and Ana F Machado. 2011. "Analysis of the Consumption of Artistic-Cultural Goods and Services in Brazil." Journal of Cultural Economics 35: 1-18. https://doi.org/10.1007/s10824-010-9129-8. 
Earp, Fabio de Silos Sá, and Luiz Manoel Estrella. 2016. “Evolução Do Mecenato No Brasil: Os Valores Movimentados Através Da Lei Rouanet Despidos Do Véu Da Inf Lação (19962014)." Políticas Culturais Em Revista 9 (1): 315-32.

Faoro, Raymundo. 2013. Os Donos Do Poder-Formação Do Patronato Político Brasileiro. Globo Livros. http://www.casaruibarbosa.gov.br/dados/DOC/palestras/Politicas_Culturais/II_Seminari o_Internacional/FCRB_AndreAugustin_O_neoliberalismo_e_seu_impacto_na_politica_cu Itural_brasileira.pdf.

Fleming, Tom. 2018. "The Brazilian Creative Economy." London.

Frey, Bruno S. 2003. Arts \& Economics: Analysis and Cultural Policy. Berlin: Springer.

Fundação João Pinheiro. 1998. "Diagnóstico Dos Investimentos Em Cultura No Brasil." Belo Horizonte.

Grampp, William D. 1989. "Rent-Seeking in Arts Policy." Public Choice 60 (2): 113-21.

Instituto Brasileiro de Geografia e Estatística. 2013. "Sistema de Informações e Indicadores Culturais: 2007-2010." Rio de Janeiro.

King, Karen, and Mark Blaug. 1976. "Does the Arts Council Know What It Is Doing." In The Economics of the Arts, edited by Mark Blaug, 101-25. London: Martin Robertson.

Kreidler, John. 1996. "Leverage Lost: The Nonprofit Arts in the Post-Ford Era." The Journal of Arts Management, Law, and Society 26 (2): 79-100.

Marsh, Leslie L. 2016. "Branding Brazil Through Cultural Policy: Rio de Janeiro as a Creative, Audiovisual City." International Journal of Communication 10: 3022-41.

Mazza, Isidoro. 2003. "Public Choice." In A Handbook of Cultural Economics, edited by Ruth Towse, 379-88. London: Edward Elgar.

Mega, Vinícius Mizumoto. 2015. “Lei Rouanet: A Visibilidade Do Produto Cultural Como Critério de Patrocínio à Produção Artística." USP. http://www.teses.usp.br/teses/disponiveis/27/27154/tde-26112015-125631/pt-br.php.

Mello, Evaldo Cabral de. 2008. "Pernambuco No Período Colonial." In Corrupção: Ensaios e Críticas, edited by Leonardo Avritzer, 183-90. Belo Horizonte: Editora UFMG.

Netzer, Dick. 2006. "Cultural Policy: An American View." In Handbook of the Economics of Art and Culture, edited by Victor A Ginsburgh and David Throsby, 1224-50. New York: Elsevier.

North, Douglass C. 1990. Institutions, Institutional Change and Economic Performance. Cambridge, MA: Cambridge University Press.

North, Douglass C, John Joseph Wallis, and Barry R Weingast. 2009. Violence and Social Orders: A Conceptual Framework for Interpreting Recorded Human History. Cambridge, MA: Cambridge University Press.

North, Douglass C., John Joseph Wallis, Steven B. Webb, and Barry R. Weingast. 2012. In the Shadow of Violence: Politics, Economics, and the Problems of Development. Cambridge, MA: Cambridge University Press.

Peacock, Alan T. 1994. "Welfare Economics and Public Subsidies to the Arts." Journal of Cultural Economics 18 (2): 151-61. 
Ploeg, Frederick Van der. 2006. "The Making of Cultural Policy: A European Perspective." In Handbook of the Economics of the Arts and Culture, 1:1183-1221.

Ponte, Elizabeth. 2012. "Por Uma Cultura Pública: Organizações Sociais, OSCIPs e a Gestão Pública Não Estatal Na Área Da Cultura." Sao Paolo.

Rodrik, Dani, Arvind Subramanian, and Francesco Trebbi. 2004. "Institutions Rule: The Primacy of Institutions Over Geography and Integration in Economic." Journal of Economic Growth 9: 131-65.

Schuster, J. Mark. 1987. "Issues in Supporting the Arts through Tax Incentives." Journal of Arts Management and Law 16 (4): 31-50.

Schuster, J. Mark. 1999. "The Other Side of the Subsidized Muse: Indirect Aid Revised." Journal of Cultural Economics 23 (1): 51-70.

Towse, Ruth. 2010. A Textbook of Cultural Economics. Cambridge: Cambridge University Press.

Throsby, David. 2010. The Economics of Cultural Policy. Cambridge: Cambridge University Press.

West, Edwin G. 1986. "Arts Vouchers to Replace Grants." Economic Affairs 6 (3): 9-16.

Zimmer, Annette, and Stefan Toepler. 1999. "The Subsidized Muse: Government and the Arts in Western Europe and the United States." Journal of Cultural Economics 23 (1): 33-49. 